\title{
Multi-scale approach for different type of drought in temperate climatic conditions
}

\author{
lonuț Minea ${ }^{1}$ (D) Marina losub ${ }^{1,2}$ (D) . Daniel Boicu ${ }^{1}$ (D)
}

Received: 27 April 2021 / Accepted: 10 August 2021 / Published online: 27 August 2021

(C) The Author(s) 2021

\begin{abstract}
Drought with its occurrence and manifestations at all levels of the natural components, yields both direct and indirect negative effects, on the ecological systems, water resources, social, as well as economic aspects of life. Therefore, any analysis that concerns this phenomenon, must be carried out at a multi-scalar level, addressing all manifestation levels (meteorological, hydrological, and hydrogeological drought). Standardized evaluation indices (for precipitation-SPI, evaporation-, -SPEI, streamflow-SDI and groundwater-SGI) have been used to analyze the evolution of the drought phenomena in Eastern Romania, for 1, 3, 6 and 12 months' time-scales, applied to seven groundwater bodies. The results of the analysis complement the observations concerning the evolution of meteorological drought (using SPI and SPEI) in the East European region, by highlighting the drought sequences of the last two decades of the last century. Those are accompanied by the meteorological drought sequences which occurred on extensive areas, starting from 2007, until present, with direct effects in river discharge and increases in groundwater level depths. The Bravais-Pearson correlation coefficient shows a close connection between meteorological and hydrological drought $(r \sim 0.45$ to 0.68$)$ and between hydrological and groundwater drought $(r \sim 0.42$ to 0.74$)$ for wells with piezometric level under $5 \mathrm{~m}$ depth. In the larger context of climate scenarios which envision an increase in air temperature, and a decrease in the atmospheric hydrological input, the increase in the drought frequency is obvious, with direct effects on all-natural components that are dependent on the hydrological resources.
\end{abstract}

Keywords Drought indices · Multi-scale approach · Correlations · Eastern Romania

\section{Introduction}

The occurrence of drought generates direct or indirect negative effects over the ecological system, economic activities, water resources and human life (Schwalm et al. 2017). Lack of rainfall, combined with higher evaporation rates, generates the occurrence of

Marina Iosub

iosub.marina@gmail.com

1 Faculty of Geography and Geology, Alexandru Ioan Cuza University of Iaşi, Iaşi, Romania

2 Institute of Interdisciplinary Research - ICI-UAIC, Integrated Center of Environmental Science Studies, North Eastern Region - CERNESIM, Iaşi, Romania 
atmospheric drought and the reduction in moisture at short time scales and water supply to the rivers at medium time scale (Tallaksen et al. 2009; Wang et al. 2016). After a longer period of the presence of atmospheric drought, a water deficit appears at groundwater level (Tallakesn and van Lanen 2004, Peters et al. 2006). In the context of climate change, the intensity and frequency of certain climatic events can provide conditions which lead to the occurrence of extreme drought, with a corresponding social and economic impact, at a global level (Trenberth et al. 2014; Vicente-Serrano et al. 2020; He et al. 2021). Identifying drought can be seen as a primordial step in the evaluation and analysis of the risk that is induced by the occurrence of this phenomenon. In this regard, standardized evaluation indices have been identified for all levels of drought manifestation. The atmospheric drought was firstly standardized by McKee et al. (1993), who described the standardized precipitation index (SPI). The obtained results have not always satisfied the working hypothesis, due to high spatial and temporal variability of rainfall and because the index does not take into account other climatic variables (van Loon 2015). Nevertheless, it is used and reviewed by a multitude of researchers, being indicated in the analysis of drought phenomena even by the World Meteorological Organization (WMO 2012, 2016). To link the atmospheric drought with the decrease in river flows, a streamflow drought index (SDI) was elaborated (Nalbantis and Tsakiris 2009). Vicente-Serrano et al. (2010), have developed the standardized precipitation evaporation index (SPEI) which takes into consideration the air temperature together with precipitation, in order to estimate water deficit as a difference between precipitation and evaporation in the climatic water balance. Recently, Bloomfield and Marchant (2013), proposed a standardized groundwater index (SGI) to analyze the occurrence and magnitude of groundwater drought. All the standardization approaches allow us to make comparisons between the different components of the hydrological cycle (atmospheric, hydrologic and hydrogeological). The applications for each index had a multi-scalar approach. The SPI was used to analyze the atmospheric drought for specific periods (Hayes et al. 1999; Rebetez et al. 2006; Vicente-Serrano 2006) and regions (Livada and Assimakopoulos 2007; Wu et al. 2007; Dubrovsky et al. 2008; Abdou and Thierry 2009; van Lanen et al. 2013; Stahl et al. 2016; Hao et al. 2018; Yeh et al. 2015; Zhao et al. 2021). The hydrological response to different time scales of climatological drought was analyzed by: Vicente-Serrano and Lopez-Moreno (2005), Tsakiris et al. (2007), Barker et al. (2016). The connection between SPI and SPEI was evaluated by Bachmair et al. (2015, 2016) Dikshit et al. (2021) and Liu et al. (2021). The SDI index was applied to identify regional streamflow drought characteristics (Vicente-Serrano et al. 2012; Tabari et al. 2013; Tigkas et al. 2015; Kermen and Onuşluel Gül 2018; Ozkaya and Zerberg 2019). The response of groundwater to climatological drought and groundwater drought was studied by Krogulek (2018), Bloomfield et al. (2019), Haas and Birk (2019), Kubicz and Bak (2019). All these indices have good statistical performance for certain types of drought: meteorological, hydrological or hydrogeological. Sometimes, the results obtained by using one index were not validated in the values produced by others, which lead to the development of more complex indices, in order to account for the multi-scalar nature of drought: Hao and AghaKouchak (2013), developed a multivariate standardized drought index (MSDI), Waseem et al. (2015) developed a new composite drought index for multivariate drought assessment, Liu et al. (2016) developed a copula-based joint streamflow drought index (JSDI), Hadi et al. (2020) created a new approach for the identification and categorization of drought in cold climate regions, the hydroclimatic aggregate drought index (HADI), and Li et al. (2021), constructed a combined drought index based on bivariate joint distribution (BCDIbcf). 
Considering the negative effects of the occurrence of drought, especially in the agricultural areas of significant importance in the European temperate climate space, the International Commission on Irrigation and Drainage (ICID) and UN Convention to Combat Desertification (UNCCD) proposed, in 2007, to develop a Drought Management Center for South Eastern Europe (DMCSEE) in order to monitor and assess the hazard, vulnerability and risk of drought in South-Eastern Europe. The addressed indices are SPI, percentiles and precipitation forecast and satellite-based products (such as Normalized Difference Vegetation Index, Vegetation Condition Index or, Soil Water Index anomalies) (Angearu et al. 2020). Most of the research concerning meteorological drought in Romania was based on the assessment of SPI (Paltineanu et al. 2008; Cheval et al. 2014; Ionita et al. 2015, 2016) and the socioeconomic impact yielded by the occurrence of this phenomenon (Ontel and Vladut 2015; Dumitrascu et al. 2018). Over the same region, the assessment of hydrological drought in the NorthEastern part of Romania, based on SDI methodology was carried-out by Minea and Sfica (2017) and the hydrogeological drought evaluation by Minea et al. (2020a, b) and Boicu et al. (2020). The occurrence of severe drought periods in the last decades (Sfica et al. 2017), generated by heat waves and warm spells, produced a significant impact on the regional water resources and led to circumstances of socioeconomic hydrological stress (Minea et al. 2020a, b).

The main objectives of this research are: (1) to evaluate different drought indicators and to analyze drought characteristics between different sites; (2) assess of the drought phenomenon, at different time scales (1, 3, 6 and 12 months) and (3) to assess the link between different drought indices. Using different time scales allows to assess the effects of lack of precipitation on different water resources component (soil moisture, streamflow, groundwater, etc.).

\section{Materials and methods}

\subsection{Study area}

The North-Eastern part of Romania, with altitudes ranging from 30 to $450 \mathrm{~m}$, is one of the driest and poorest regions in the country. Significantly exposed to continental dry air masses, severe drought events are quite frequent in the area, which contains extensively used agricultural land (Rusu et al. 2020). According to European Framework 2000/60/EC, in this area, seven groundwater bodies were identified (six at regional level and one cross-border with Republic of Moldova, in the East): upper flood plain of Prut River and its tributaries (coded ROPR01), middle flood plain of Prut River and its tributaries (ROPR02), flood plain of Bârlad River and its tributaries (ROPR03), Covurlui Plain (ROPR04), Central Moldavian Plateau (ROPR05), Tecuci Plain (ROPR06) and Moldavian Plain (ROPR07) (Fig. 1). All groundwater bodies belong to the porous type, accumulated in Quaternary and Sarmatian-Pontian deposits, and have a free groundwater level relatively close to the surface, and are subject to climatic and human pressure. To that end, in our analysis we will use this territorial division to identify the correlations between meteorological and hydrogeological drought (Table 1). 


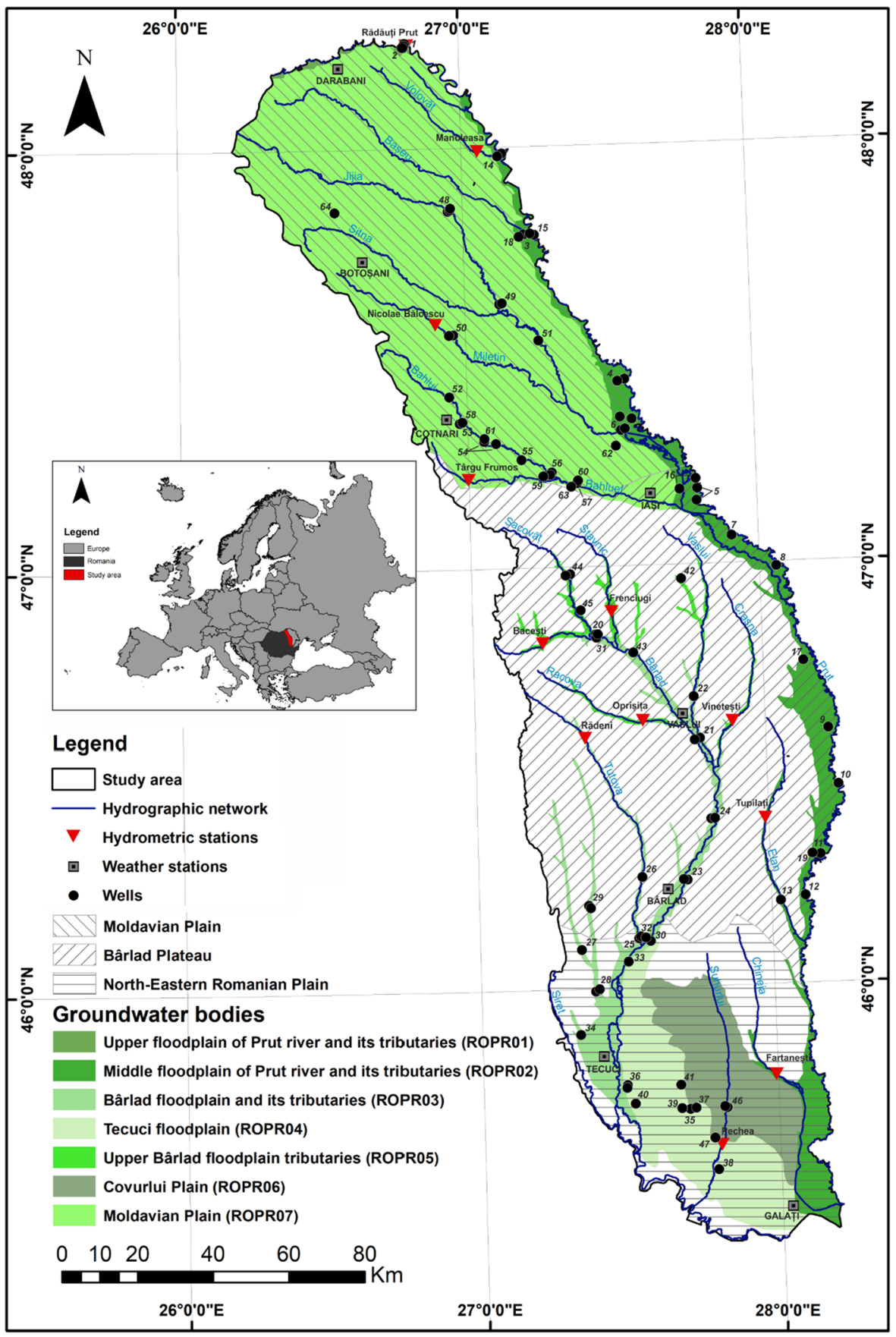

Fig. 1 Geographical location of study area 


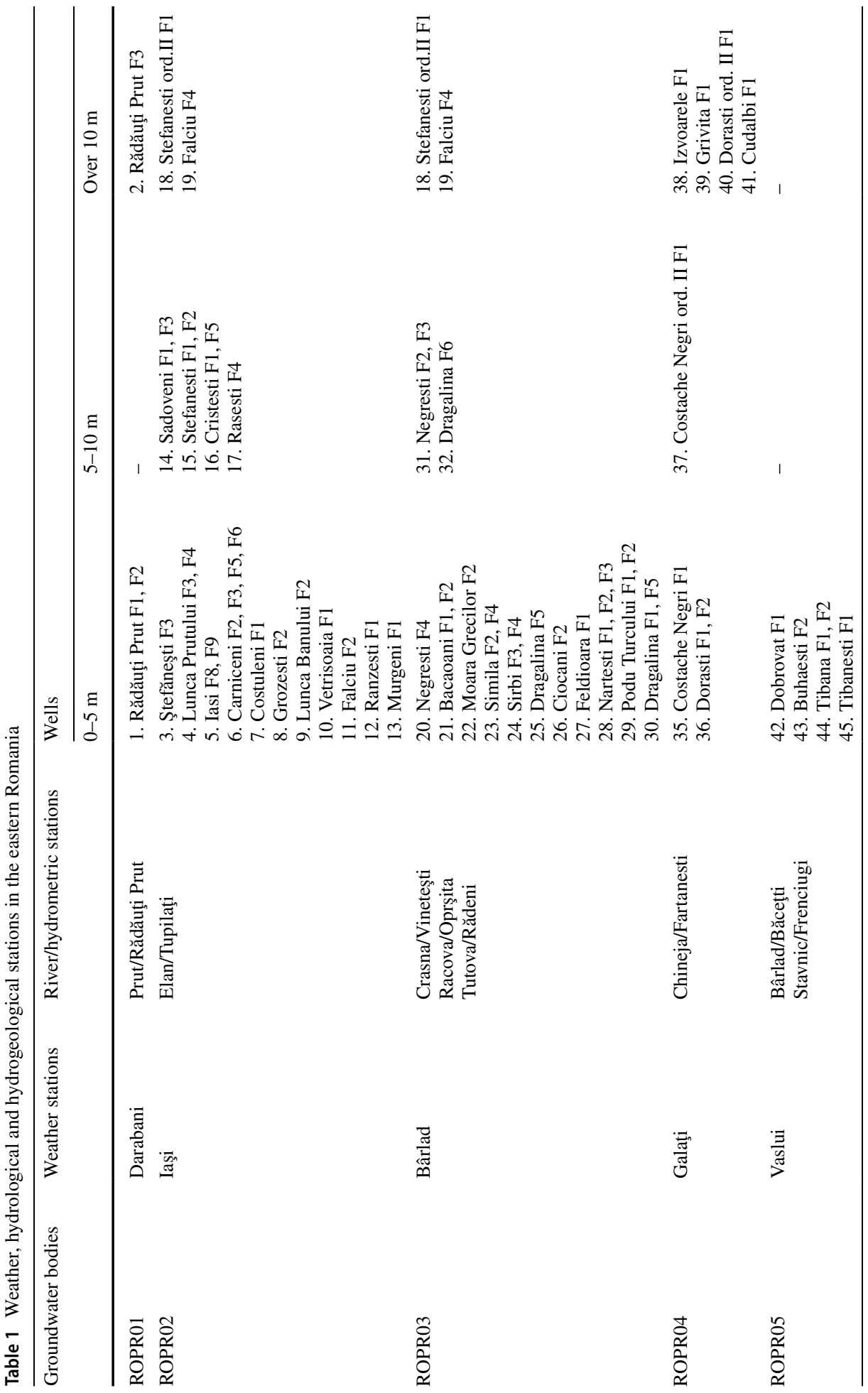




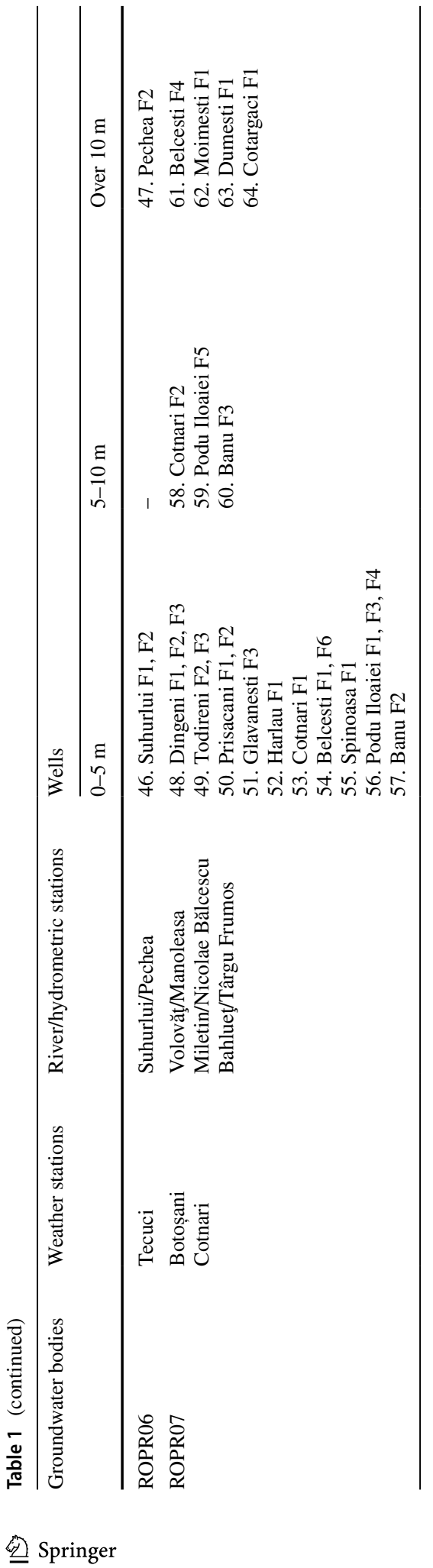




\subsection{Meteorological datasets}

The analysis of the meteorological drought indices was based on monthly values for temperature $\left({ }^{\circ} \mathrm{C}\right)$, and precipitation $(\mathrm{mm})$, extracted for 8 weather stations, uniformly distributed throughout Eastern Romania. The data covered 36 years, continuously, from 1983 to 2018, and were extracted from the ROCADA climate dataset, provided as a grid database by the National Meteorology Administration (Dumitrescu and Bîrsan 2015) for the 1983-2013 period, and from the ERA 5 model produced by European Centre for Medium-Range Weather Forecasts, within the Copernicus Climate Change Service (C3S) (Hersbach et al. 2020) for the 2014-2018 period.

\subsection{Hydrological and hydrogeological datasets}

For the analysis of the hydrological and hydrogeological drought, the used database is comprised of 12 hydrometrical and 64 hydrogeological stations (with one or multiple hydrogeological drillings included), located in the North-East region of Romania, in a plain area, with relatively homogenous geographical characteristics. The criteria used for selecting the hydrometrical stations were as follows: (i) to be located in hydrographic basins with insignificant anthropic impact, where the river discharge regime would best reflect natural conditions; (ii) to have river discharge measurements that span across a long period of time, of more than 30 years. For the hydrogeological drillings, the criteria to be met were: (i) to be free of anthropic influence (via collecting or underground water seeping); (ii) to have piezometric level measurements that span across a long period of time (more than 30 years); (iii) to have the unconfined or semi-confined aquifer phreatic level variation well-highlighted in the piezometric levels data. Considering the evolution of the hydrologic and hydrogeological regime, the analysis periods for al parameters (precipitation, evapotranspiration, river discharge and piezometric level) have been defined according to the hydrological year time-frame, from October to September next year. For the autumn season, October to December, January to March for winter, April to June for spring and July to September for summer. The analysis timeframe spans from October 1983 to September 2018, resulting in 36 hydrological years. The entirety of the hydrological and hydrogeological database used comes from the Prut Bârlad Basin Branch of the Romanian National Water Administration.

\subsection{Methods}

In order to perform the drought analysis, 4 specific indices were involved: 2 for highlighting the atmospheric drought: standardized precipitation index (SPI), standardized pluviometric evapotranspiration index (SPEI), one for the hydrologic drought: streamflow drought index (SDI) and one for the hydrogeological drought, the standardized groundwater index (SGI), respectively. 


\subsubsection{SPI and SPEI}

The SPI methodology established by McKee et al. (1993) quantify the above average rainfall anomalies, on certain time intervals: 1, 3, 6, 12, 24 or 48 months. The SPI equation falls under the cumulative gamma distribution type, for two parameters:

$$
G(x)=\frac{1}{\beta^{\alpha} \tau(\alpha)} \int_{0}^{x} x^{\alpha-1} e^{-x / \beta} d x, \text { for } x>0
$$

where $G=$ the gamma distribution, $x=$ the monthly precipitation value, $\alpha=$ the shape parameter, $\beta=$ the scale parameter, $\tau(\alpha)=$ the gamma function, $d x=$ the density function. The gamma distribution is undefined for $x=0$, but monthly precipitation can have a value of 0 . In this case the probability for the cumulative distribution which is assigned a value of 0 , is derived from the following:

$$
H(x)=q+(1-q) G(x)
$$

where $q=$ the occurrence probability of a value of 0 for monthly precipitation (LloydHughes and Saunders 2002). In this case, the cumulative probability distribution is transformed into a normal distribution for calculating SPI. The results were classified as follows: SPI values under -2 correspond to extreme drought, SPI values between -2 and -1.5 correspond to severe drought, SPI values between -1.5 and -1 correspond to moderate drought, SPI values between -1 and 0 correspond to minor drought and SPI values over 0 show no drought has occurred.

Since it reflects the conditions induced by thermo-hydric stress over surface and ground water resources, Vicente-Serrano et al. (2010) introduced the SPEI index. Based on the evolution of the monthly climatic water balance (precipitation minus potential evapotranspiration), this index was adjusted using a three-parameter log-logistic distribution. Following the same methodology used for obtaining the standardized precipitation index the SPEI was calculated for monthly values and merged for seasonal and annual values.

$$
\mathrm{SPEI}=W-\frac{C_{0}+C_{1}+C_{2} W^{2}}{1+d_{1} W+d_{2} W^{2}+d_{3} W^{3}}
$$

where

$$
W=\sqrt{-2 \ln (P) \text { for } P \leq 0.5}
$$

and $P$ is the probability of exceeding a determined $D$ value, $P=1-F(x)$. If $P>0.5$, then $P$ is replaced by $1-P$ and the sign of the resultant SPEI is reversed. The constants are $C_{0}=2.515517, C_{1}=0.802853, C_{2}=0.010328, d_{1}=1.432788, d_{2}=0.189269$, and $d_{3}=0.001308$. The average value of SPEI is 0 , and the standard deviation is 1 . The SPEI is a standardized variable, and it can therefore be compared with other SPEI values over time and space. An SPEI of 0 indicates a value corresponding to $50 \%$ of the cumulative probability of $D$, according to a log-logistic distribution.

The $D$ probability is defined for time series of $1,3,6,12,18$ and 24 months and is calculated using the following equation: 


$$
F(x)=\left[1+\left(\frac{\alpha}{x-\gamma}\right)^{\beta}\right]^{-1}
$$

where $\alpha, \beta$ and $\gamma$ are scale, shape, and origin parameters, respectively, for $D$ values in the range $(\gamma>D<\infty)$. The results were classified as the same with SPI.

\subsubsection{SDI}

Developed by Nalbantis and Tsakiris (2009) and using the same methodology associated with SPI, the SDI identifies drought events with reference to a particular site. Using monthly streamflow values and the methods of normalization associated with SPI, the hydrological drought periods can be investigated using equation:

$$
Q_{i, j}=v \sum_{j=1}^{3 k} q_{i, j} i=1,2,3, \ldots j=1,2,3, \ldots, 12 k=1,2,3,4
$$

where $Q_{i, j}$ is the cumulative streamflow volumes, and $q_{i, j}$ is the total streamflow volumes for the $i$ th hydrological year and the $k$ th reference period. The index " $j$ " refers to the month in the hydrological year, and $\mathrm{k}$ index refers to the month number.

To verify the goodness of fit of the streamflow values, the Kolmogorov-Smirnov (K-S) test for the 0.05 significance level was used. Also, to decrease the skewness values of the all-streamflow series, the log-normal distribution was used. The results were classified according to the SPI results classifications.

\subsubsection{SGI}

For groundwater, the SGI proposed by Bloomfield and Marchant (2013) has been used. This index is also based on the SPI methodology, but instead of using a gamma or log-normal distribution to transform the data series, it uses a nonparametric normal score transform. This is due to the fact that the SGI does not reflect an accumulation over specific period, because of the nature of the underlying groundwater level (Bloomfield and Marchant 2013). The nonparametric normalization assigns a value to the measured groundwater level, based on its rank within a data set (from a specific month in a specific year). The normalization is made by applying the inverse normal cumulative distribution function to data series. The resulting values fall in the $1 / 2 \mathrm{n} /$ to $1 / 1-2 \mathrm{n}$ interval and the SGI distribution passes the Kolmogorov-Smirnov test for normality. After obtaining the SGI values for each month, we could calculate the SGI values for seasons and years. The results can be classified according to the drought indices mentioned before.

\subsubsection{Correlation between drought indices}

Natural systems have their own, different response to a context that involves a hydrological deficit, in depending on the lithology and land cover (Vicente-Serrano et al. 2012). This is one of the reasons for performing the analysis at different temporal scales, from 1 to 12 months. Considering that the response times in hydrological deficit conditions is different from one system to another, the Pearson correlation coefficient, $r$, was computed for 
all variables, in order to identify the time-frames which exhibit a link between the various drought types and for highlighting their propagation.

\section{Results}

All drought indices were estimated at 4 level time scales (1-month, 3-month, 6-month and 12-month) for every groundwater body. If several observation points for precipitation, river discharge and groundwater level variation exist for one water body, the final values for each calculated index were the averages for all values obtained at each observation point. The resulting data were correlated for both space and time for each drought index and then at correlation matrix level, for each time-frame in the analysis.

\subsection{Climatological drought evaluation}

The time scales used for the SPI and SPEI evolution in Eastern Romania (e.g., 1, 3, 6, 12 months) reflect the impact of drought on the availability of different surface and underground water resources. At short time scale, 1 month for SPI and SPEI and 3 months for SPI and SPEI, the values emphasize a high tendency of frequent fluctuations between the sequences of dry and wet years, for all groundwater bodies. During these sequences, a period of moderate to severe drought is clearly highlighted by the SPI 3 analysis, from June 1986 to June 1987 (except ROPR01) and from December 1989 to December 1990 (Fig. 2). Increasing the time scale to SPI 6 and SPI 12, and the frequency of the sequenced between the drought periods is reduced significantly, but have a longer duration. An extreme drought period is appearing clearly according to SP 12 analysis, for all water bodies, during November 1986-May 1988, followed by a moderate to severe drought period between May 1990 and April 1991, June 1992 and March 1993, March 1994 and April 1996, June 2000 and August 2001, November 2011 and December 2012, except for ROPR03 and ROPR06).

The frequency of extreme drought periods has a variation of $1 \%$ in the entire analyzed time-frame for SPI 3 (for ROPR02) to 4\% for SPI 12 (for ROPR03, ROPR05 and ROPR06). Severe drought frequency varies between 4 and $6 \%$ for all groundwater bodies and time scales and moderate drought frequency varies between 8 and $12 \%$ for SPI 1, SPI 3 and SPI 6, and 7-14\% for SPI 12 (Fig. 3). The lowest values of SPI (from -2.7 for ROPR06 to -3.8 for ROPR04 and ROPR07) were observed for SPI 1 for all groundwater bodies, with tendencies to attenuate the minimum values for SPI 6 and SPI 12 (from -2.2 for ROPR01 to -3.5 for ROPR05). August 2018 was the month the lower values for SPI 1 in the Northern part of the region (ROPR01 and ROPR07) and July 2007 for the Southern part of the region (ROPR05 and ROPR06). Between October 1986 and September 1987, the lowest values of SPI 12 for 6 out of 7 groundwater bodies were calculated (except for ROPR02). The cumulated month with severe to moderate drought does not exceed 85 months for any groundwater body and time scale for SPI.

The SPEI index takes into account the air temperature in addition to precipitation to evaluate water deficit. Because of that, this index is more sensitive to changes in drought, and in the time scale evolution, slight differences in the fluctuation value and continuity with SPI evolution can be observed. The difference decreases with an increase in the timescale. Increasing air temperature and reduction in precipitation as an impact of regional climate change will affect the duration and severity of drought and water resources from both surface and underground (Minea and Croitoru 2017). The evolution of SPEI 1 and 

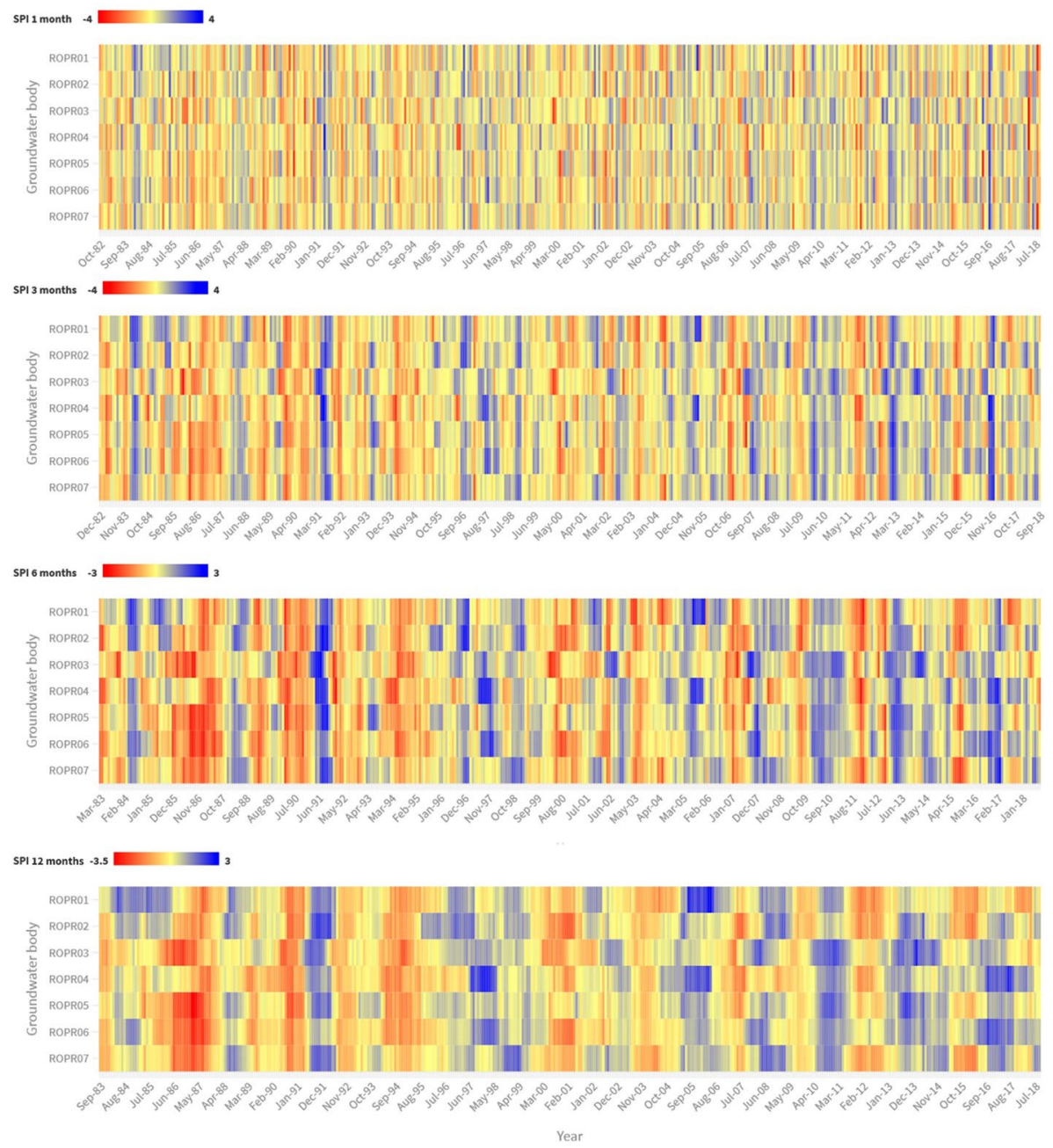

Fig. 2 Evolution of SPI for groundwater bodies in Eastern Romania

SPEI 3 for the Eastern part of Romania has the same pattern as SPI 1 and SPI 3, with slight differences in terms of the duration of drought periods. Extreme drought does not exceed $1 \%$ of cases for all groundwater bodies and time scales. Moderate drought frequency varies between 4 and 6\% for SPEI 3 and SPEI 6, and 5-8\% for SPEI 12. The lowest value of SPEI 1, -3.7 was calculated for ROPR01 (in August 2018, when the monthly amount of precipitation at the Darabani weather station was the lowest in all data series, $0.4 \mathrm{~mm}$ ). For 3 out of 7 groundwater bodies, the lowest values were calculated for SPI 1 for April 1990 (after a dry and warm winter in the central region). The cumulated month with extreme and severe drought does not exceed 30 months for any groundwater body and time scale for SPEI. At $14 \%$ of all groundwater bodies and SPEI time scale, the values of the cumulated month from severe to moderate drought are higher than at SPI values. At the level of ROPR07, the longest duration of dry events with 10 months with severe and extreme drought were calculated, for SPEI 6 and SPEI 12. The sequence of wet and dry periods is better highlighted 


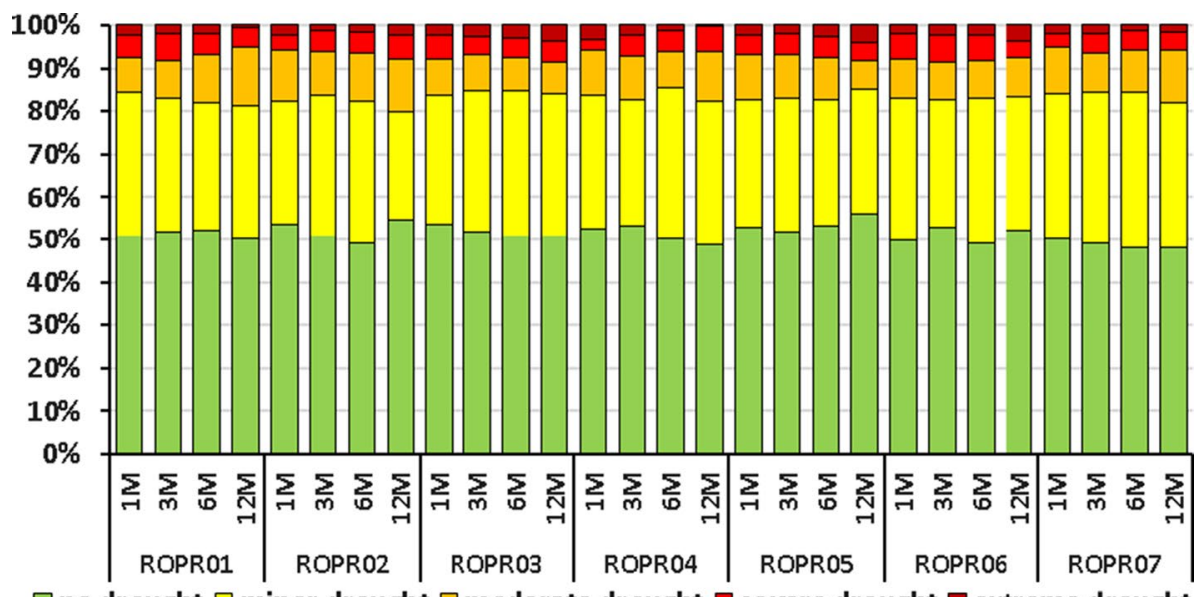

$\square$ no drought $\square$ minor drought $\square$ moderate drought $\square$ severe drought $\square$ extreme drought

Fig. 3 Cumulated drought periods frequency using SPI for groundwater bodies in Eastern Romania

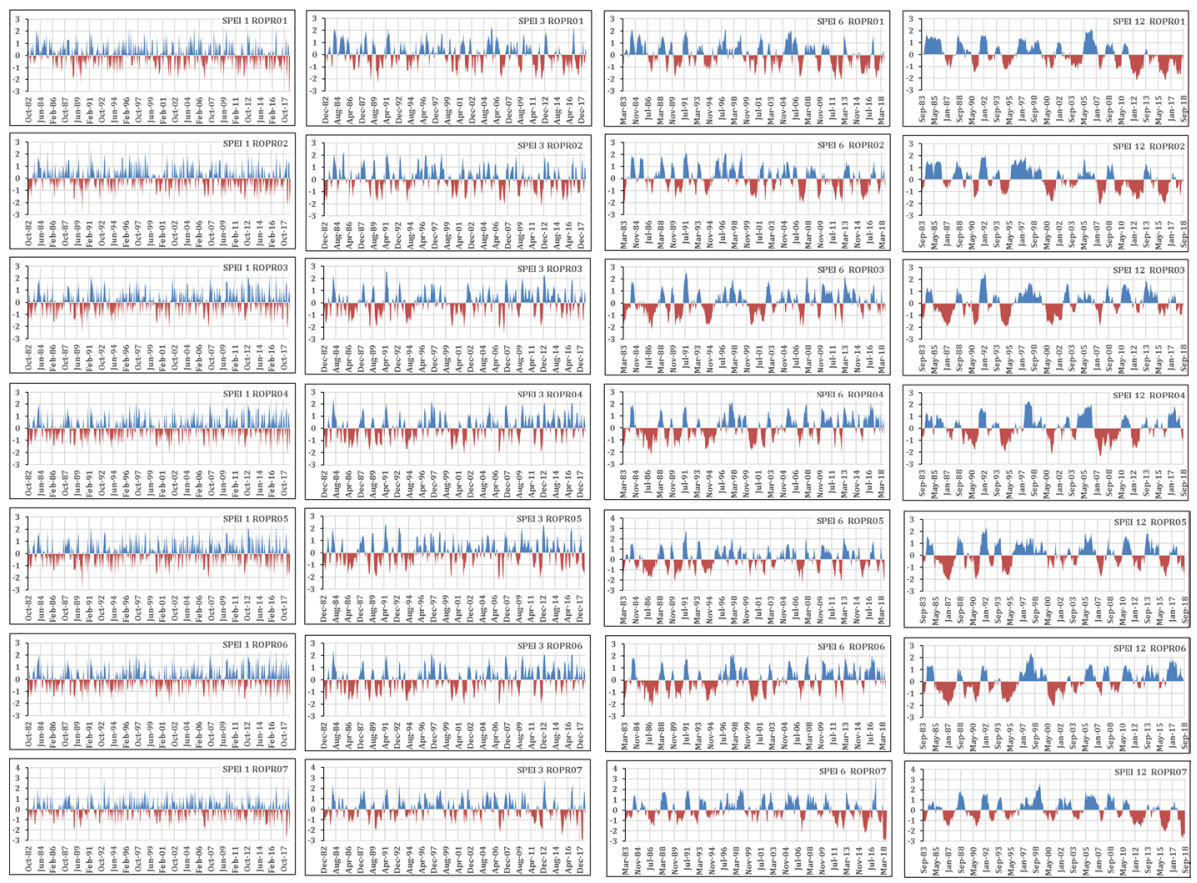

Fig. 4 Evolution of SPEI for groundwater bodies in Eastern Romania

using the SPEI 6 and SPEI 12 with an increasing frequency of drought periods and intensity from April 1985 to November 1987 for ROPR03, ROPR04 and ROPR06, from October 1999 to June 2002, with a maximum duration for ROPR03 and from May 2011 to September 2018 to a maximum intensity for ROPR01, ROPR02 and ROPR07 (Fig. 4). 


\subsection{Hydrological drought evolution}

The hydrological drought highlights the impact over surface water resources, as a consequence of the propagation of climate drought in the natural systems. The SDI analyses were carried out for each groundwater body, for different time-frames, just as with SPI and SPEI. The evolution of SDI has a different pattern as evolution of the other indices across the time scale, because of the influence of local conditions, which hinder or favor the water input in the river flow from precipitation. In the same time, the propagation of the hydrological drought can be influenced by the base flow, which in this area has an important role in runoff (Minea and Sfî̀că 2017). The SDI 1 and SDI 3 evolution reveals a sequence with low flow and normal or high flow, but without frequent fluctuations as in the case of SPI 1, SPI3 or SPEI 1 and SPEI 3 (Fig. 5). Even at this time scale, the occurrence of successive periods with extreme or severe hydrological drought at all groundwater body levels can be observed (from February 1986 to November 1987, from November 1989 to April 1991 and from May 2011 to February 2013). Most of these periods overlap with or, are a consequence of periods of climatic drought. The SDI 6 and SDI 12 reveal three major hydrological drought who affect this region. One starting in 1986, continued with minor periods, with sequences of hydrological normality, until 1995, which affected entire region, another one at the beginning of the twenty-first century, starting in 2000 and ending in 2007, which affected mostly the central part of this region, and a third one, starting in 2012 and continuing until 2018, which affected the Northern and Eastern parts of this region.

The effect of cumulated climatological water deficit, with hydrological and hydrogeological features of drainage basins, generates circumstances which are capable of
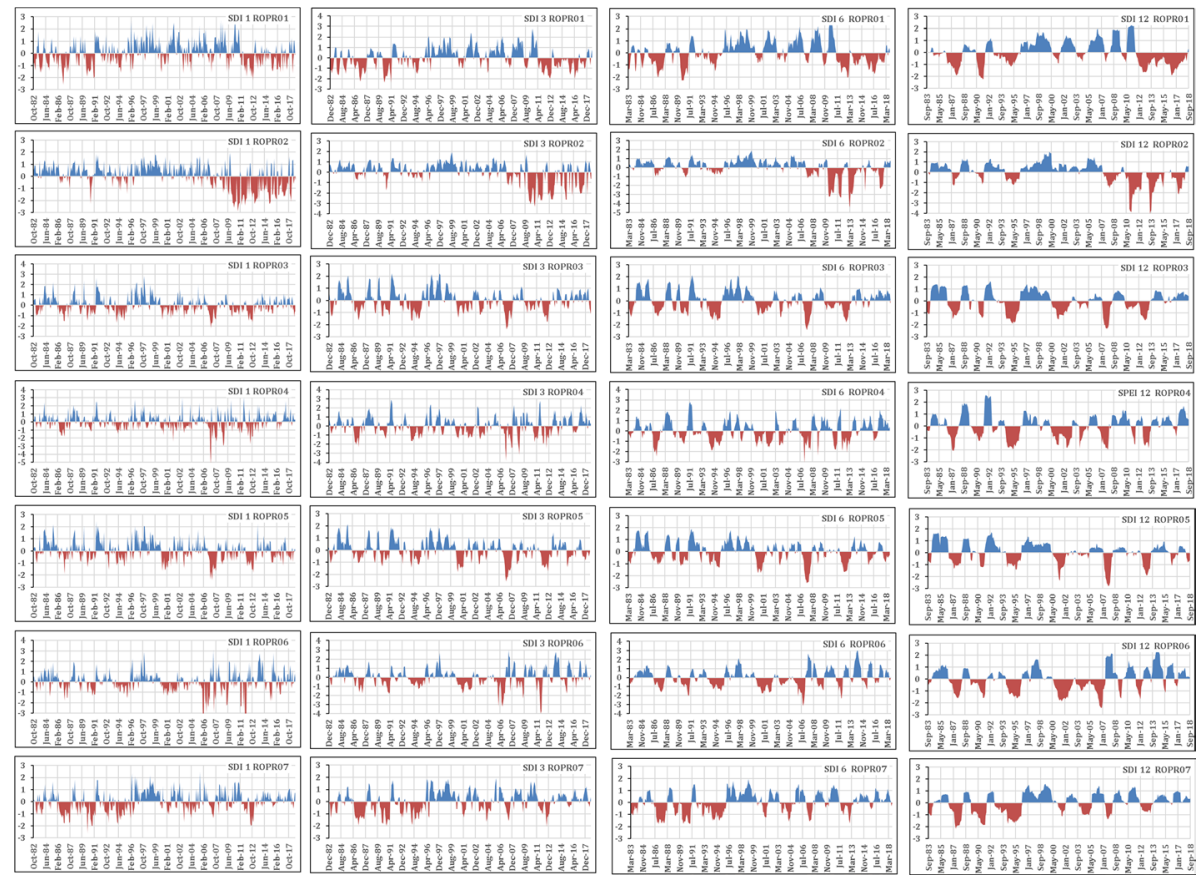

Fig. 5 Evolution of SDI for groundwater bodies in Eastern Romania 


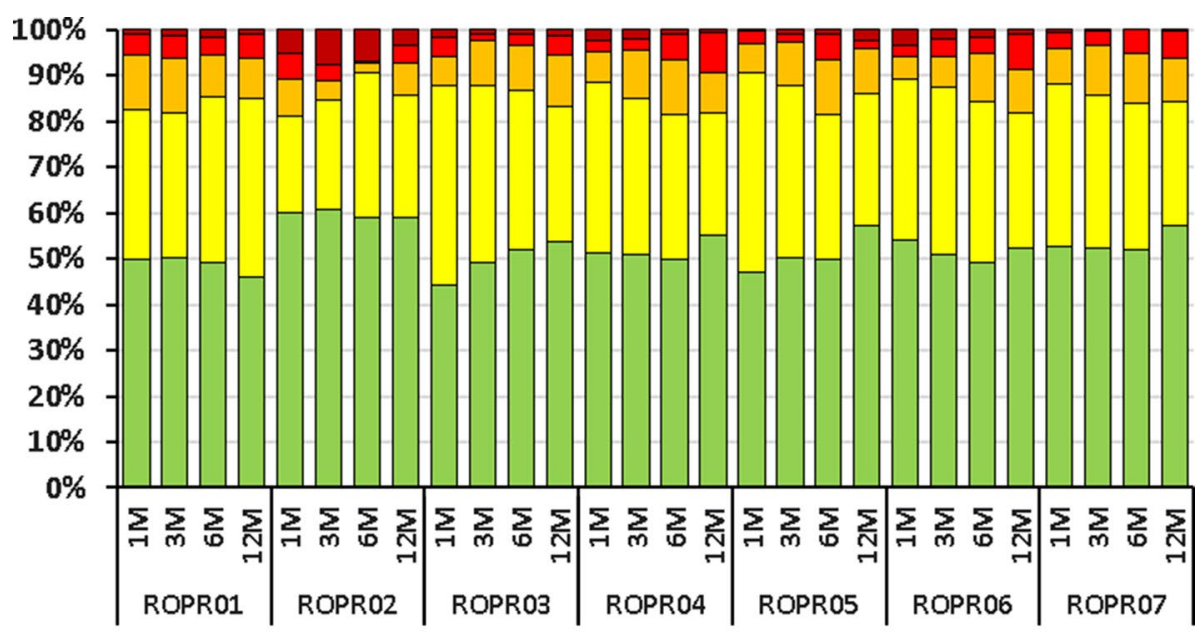

$\square$ no drought $\square$ minor drought $\square$ moderate drought $\square$ severe drought $\square$ extreme drought

Fig. 6 Cumulated drought periods frequency using SDI for groundwater bodies in Eastern Romania

producing extreme and severe hydrological drought. One month-SDI frequency for the extreme drought, falls between 1 and 7\% (with the maximum calculated for ROPR02) and for severe drought it falls between 3 and $9 \%$ (with the maximum for ROPR04). The lowest values of SDI, -4.3 , were calculated for SDI 1 for ROPR04. The cumulated month with extreme and severe hydrological drought varies between 13 (ROPR05) and 47 (RORP02) months for SDI 1 and 19 (ROPR05) and 40 (ROPR02) months for SDI 12 (Fig. 6). The moderate drought frequency is in the same percentage range as the moderate drought frequency for SPI and SPEI (between 27 and 44\%).

\subsection{Groundwater drought evolution}

As a final effect of the manifestation of meteorological and hydrological drought, the hydrogeological ones depict the total impact of the precipitation deficit on the groundwater resources. The SGI's evolution cumulates the occurrence of meteorological and hydrological drought with the geological particularities of the aquifers of a given region. For the Eastern region of Romania, such aquifers are established into clay and clay-marl deposits in the North and sandy or clay-sandy deposits in the South. This lithology leads to a groundwater accumulation as well as a specific response to the hydric input from the surface water (be it from precipitation or the hydrographic network). The SGI values, for all the groundwater bodies, are significantly lower, due to the cumulative effect of the lithological characteristics and the depth of the phreatic level. The cumulated frequency for the different types of drought, supersedes the frequency of drought-free periods, which emphasizes the negative effect of the lack of precipitation on the entire region. However, the occurrence and frequency of extreme and severe drought are found to be diminished, in favor of the moderate and minor drought phenomena. Besides, for the 1-month SGI, the frequency of the extreme drought is 0 for the hydrogeological drillings with depths of the hydrogeological level of under $5 \mathrm{~m}$, for all the water bodies, with slight increases to frequencies of 1-3\% for the hydrogeological drillings with the hydrogeological level located at 5-10 m, or over $10 \mathrm{~m}$. Due to the cumulated 
effect of the geological conditions and the time-scale for the groundwater drought, most extreme and severe hydrogeological drought periods occur for the 6 and 12 month-SGI (for ROPR01 and ROPR06 for wells with groundwater level under $5 \mathrm{~m}$, for ROPR02 and ROPR04 for wells with groundwater level between 5 and $10 \mathrm{~m}$, or for ROPR01 and ROPR07 for wells with groundwater level over $10 \mathrm{~m}$ ) (Fig. 5). The moderate and minor groundwater drought have the highest frequency for all groundwater bodies with cumulated values between 34 and 59\%. For some groundwater bodies, such as ROPR04 (for wells with groundwater level over $10 \mathrm{~m}$ ) or ROPR07 (for wells with groundwater level between 5 and $10 \mathrm{~m}$ ) groundwater drought had insignificant manifestations (just minor drought appeared in all analyzed periods) (Fig. 7).

The evolution of hydrogeological drought follows the same pattern as the one exhibited by the meteorological and hydrological drought in the region. The manifestation periods of hydrogeological drought are slightly delayed, in accordance with the analysis time-scale and the local geological conditions. For the hydrogeological drillings with depths of the hydrological level of under $5 \mathrm{~m}, 1$ month- and 3-month SGI levels reveal important drought periods, followed by wet periods but without the high tendency of fluctuation, such as in case of SPI or SPEI for the same time-scale. The 6-month and 12 month-SGI reveal important groundwater drought periods between May 1986 and May 1988 (with different drought periods and intensities for each groundwater body, larger in the case of ROPR01 and lower in the case ROPR03), February 1990 to April 1991, February 1994 to November 1995, May 2000 to May 2001, March 2006 to February 2008, April 2012 to September 2018 (except ROPR06, with 2 minor wet periods in 2014 and 2017) (Fig. 6). For groundwater depth between 5 and $10 \mathrm{~m}$ and over $10 \mathrm{~m}$, the groundwater drought appears more intense, with minimal SGI values $(-2.24$ for 1 month-SGI for ROPR04 in December 1996, and -2.93 for 1 month SGI for ROPR01 in April 1998). The groundwater drought evolution has different patterns for each groundwater body, depending on the phreatic level depth and the local geological conditions. For the hydrogeological drillings with depths between 5 and $10 \mathrm{~m}$ in the time-frame after 2011, we can distinguish the manifestation of an ample hydrogeological drought (except for ROPR04) (Figs. 8, 9 and 10).

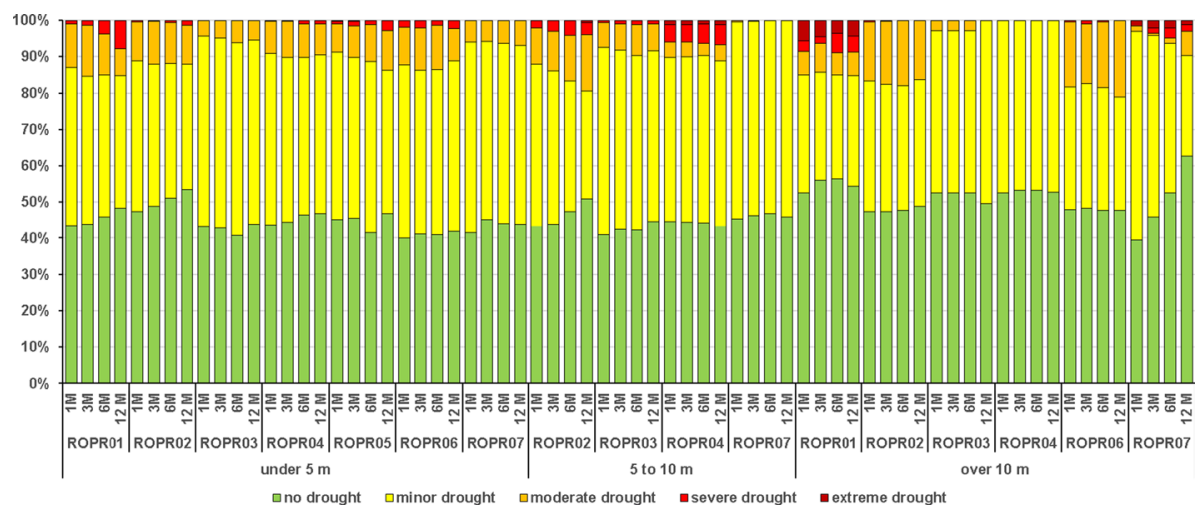

Fig. 7 Cumulated drought periods frequency using SDI for groundwater bodies in Eastern Romania 


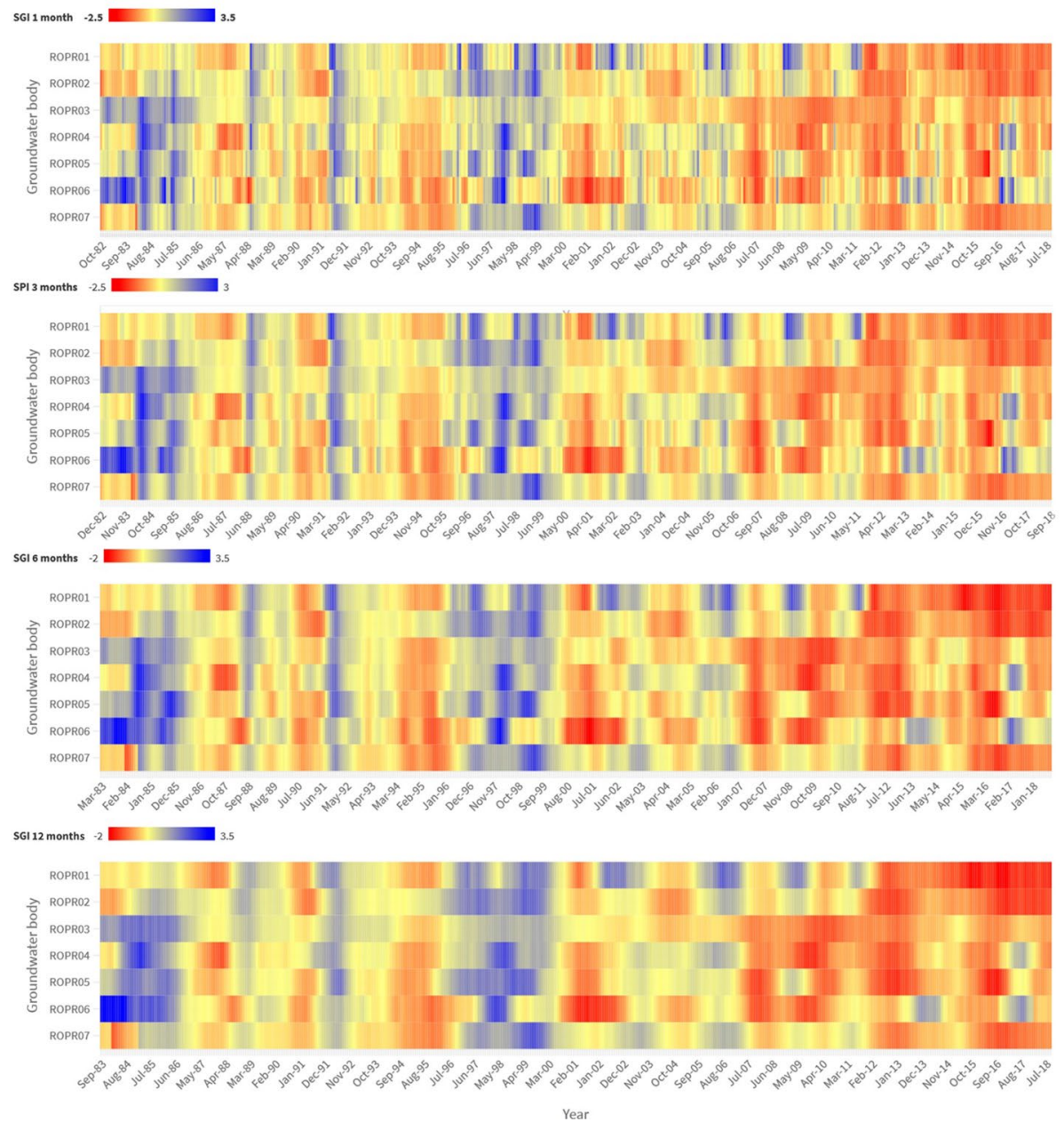

Fig. 8 Evolution of SGI for well with groundwater depth under $5 \mathrm{~m}$

\subsection{Correlation between drought indices}

To determine the correlation between different drought indices, the Bravais-Pearson linear correlation coefficient was used. The same method has been successfully used in many studies worldwide (Kundzewicz et al. 2005; Leelaruban et al. 2017). In this study, the distances between the wells, hydrological and weather stations, for each groundwater body, were taken into account when determining the type of correlation. The variations of the groundwater level are nearly entirely dependent upon the geological features of the host rocks and the water input from the surface, and this will affect the results concerning the correlation between the different drought indices, which can vary greatly, even in areas that are hydrogeological homogeneous. The geological deposits of the area play an important role, which favors or not the infiltration of precipitation, allowing it to quickly reach the water table. 


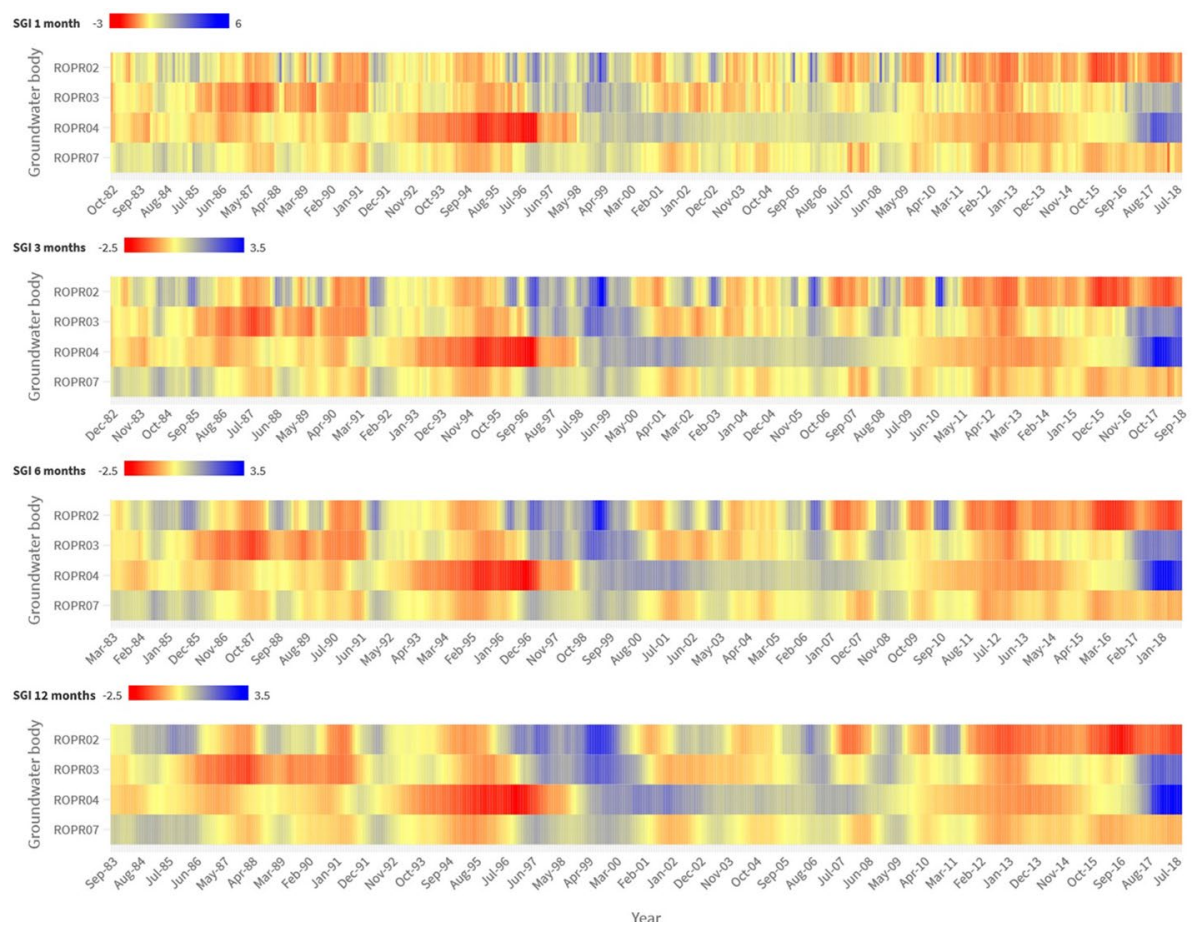

Fig. 9 Evolution of SGI for well with groundwater depth under between 5 and $10 \mathrm{~m}$

SPI and SPEI indices are very well correlated, considering that in the calculation of SPEI for different time-scales, the precipitation has an important role, along air temperature. The correlation coefficient between these two indices varies from 0.89 to 0.96. Much lower is the correlation coefficient between SPI, SPEI and SDI. For ROPR01 (except 1-month time-scale), ROPR05, ROPR06 and ROPR07 (for 6 and 12-month time-scale), the correlation coefficient shows a close connection between meteorological drought and hydrological drought $(r \sim 0.45-0.68)$. Between SPI/SPEI and SGI for groundwater levels under $5 \mathrm{~m}$ and between 5 and $10 \mathrm{~m}$, direct correlations (statistically significant) were identified for only 3 groundwater bodies (ROPR01, ROPR02 and ROPR03) and for the 6 and 12-month time-scale (Fig. 11). These values converge toward the same type of results obtained by Minea and Croitoru (2017), which highlights for the Northern part of this region that a direct correlation exists, between precipitation and groundwater level, for more than $80 \%$ of the coupled weather stations-wells in summer and autumn seasons.

The low values of the correlation coefficient calculated for SPI/SPEI and SGI for 1 and 3-month time-scale (generally under 0.3 ) are a direct consequence of the influence of the geological features in the redistribution of the monthly volume of atmospheric water in the underground. Statistically significant values of correlation coefficient were found between SDI and SGI for groundwater levels of under $5 \mathrm{~m}$. For 5 out of 7 groundwater bodies (except ROPR004 and ROPR06) the correlation coefficient between these two indices varies from 0.42 to 0.74 . 


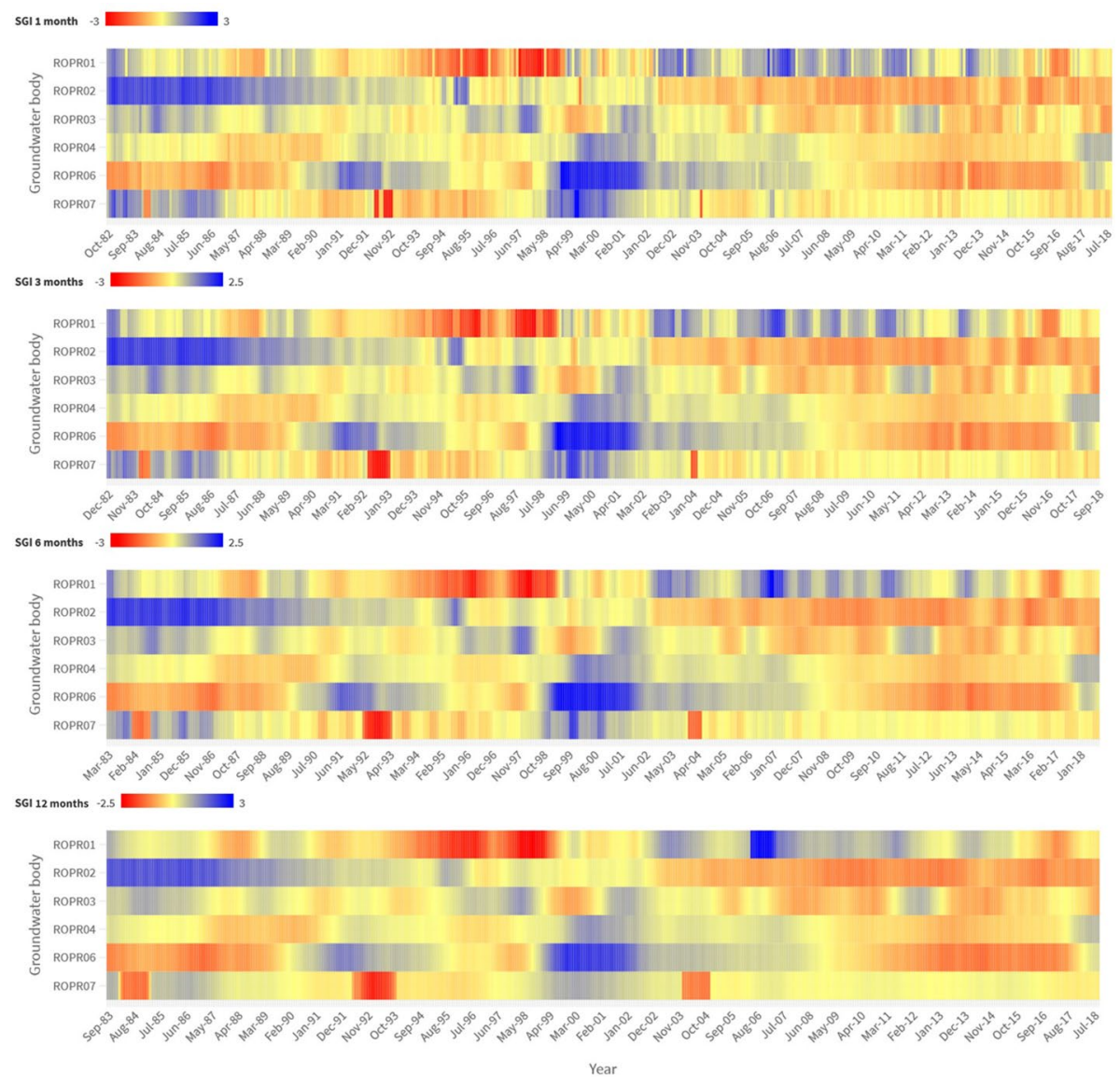

Fig. 10 Evolution of SGI for well with groundwater depth over $10 \mathrm{~m}$

\section{Discussions}

The negative effects of the occurrence of drought can be experienced on multiple facets (climatic, hydrological and hydrogeological), and when present for extended periods of time, determine increases in social and economic vulnerability for entire regions (Nistor 2019). The past and projected variability of the climatological parameters (air temperature, precipitation, evapotranspiration and aridity) in the South-Eastern Europe suggests an increasing warming of the region, which yields increasing aridity (Cheval et al. 2017). Moreover, the evaluation of the water balance in this region, shows a negative trend of precipitations and an increase in the evapotranspiration, with effects on surface and groundwater resources (Prăvălie et al. 2018). The research carried out at a national level signaled the shift, in the last decades, of large areas of the country, toward drier conditions (Croitoru et al. 2013; Dumitrescu et al. 2015). All these studies suggest an increasing potential for producing climatological drought and in direct connection with it, the hydrological and hydrogeological drought. The SPI and SPEI for different time-scales show similar results when observing the drought conditions averaged over the entire Danube River's catchment 


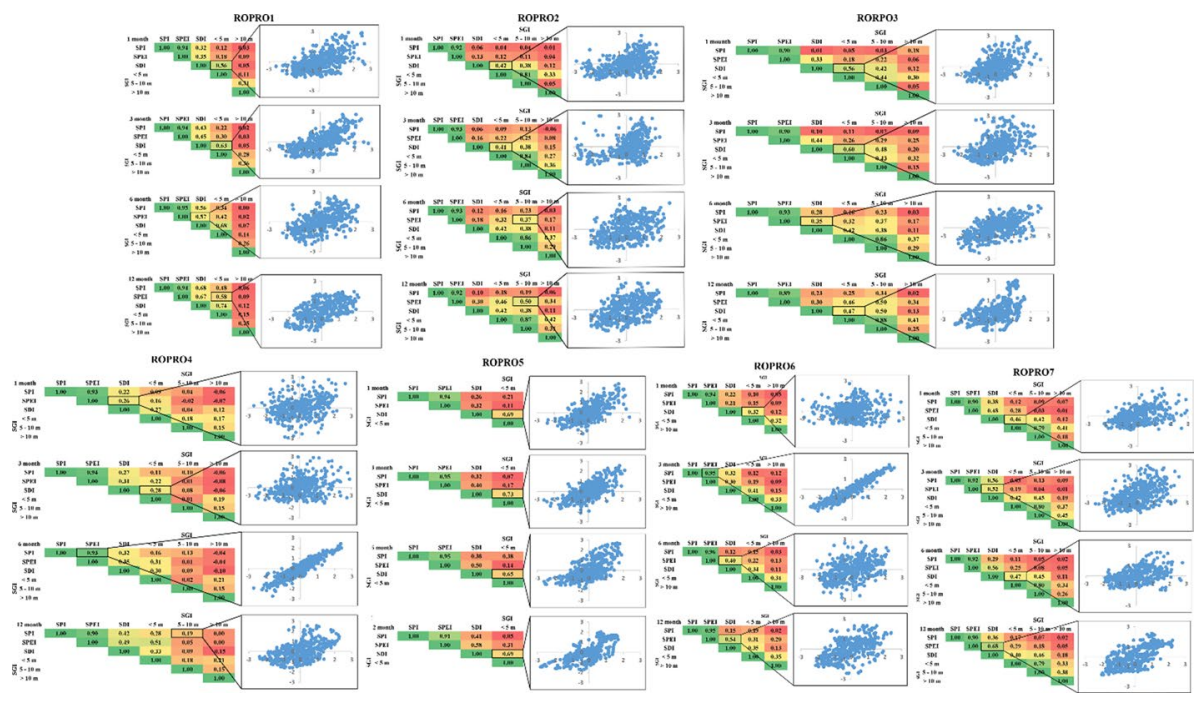

Fig. 11 Correlation between different types of droughts at the level of each groundwater bodies

area. The prolonged dry period from 1982 to 1996 highlighted by Ionita et al. (2015), was also identified in Eastern Romania with minor spatial differences. This period is continued after the year 2000 by the appearance of another three periods of climatic drought (from October 1999 to June 2002, from May 2007 to May 2010 and from May 2011 to September 2018) with maximum intensity and duration in the North-Eastern and Eastern parts of Romania. Basically, the drought period that was signaled at the end of the last century, continues to develop in this region in the current century (Spinoni et al. 2015; Hanel et al. 2018). The period after 2000 was characterized through a constant increase in the yearly average temperature, as well as the heatwaves, coupled with the occurrence of extreme pluviometric events, which exhibited alternations of periods of pluviometric excess and deficit (Field et al. 2014; EDO 2021). The prolonged dry periods caused an increase in drought frequency and severity in Southern Europe and the Mediterranean area (Vicente-Serrano et al. 2011; Ionita et al. 2017) and Eastern Europe (Mokhov 2011), with an impact over the environment and economical activities (Trenberth et al. 2014). The climatological drought influences the occurrence and evolution of hydrological drought. Sometimes, in special conditions, this connection is highlighted by analyzing the mechanisms of drought propagation, such as experienced in 2018, when record-breaking temperatures were recorded in Northern Europe, from May to August (Bakke et al. 2020), which influenced the propagation of the hydrological drought. The same situation was observed in this study, with a clear occurrence of climatological and hydrological drought in the North-eastern part of Romania.

The response of the streamflow and groundwater levels to the climatic input is often delayed and diffuse. Usually, the occurrence and duration of hydrological and groundwater drought may vary greatly from site to site (Van Loon 2015). For the Eastern part of Romania, the delay time between the climatological, hydrological and groundwater drought is well highlighted at the 1-month and 3-month time-scale. For monthly ranks between 6 and 12 of precipitation, streamflow and groundwater, the delay time is reduced and the periods of hydrological groundwater drought overlap mostly with those of climatological drought. 
These connections were analyzed at continental level for drought for 2015 (Laaha et al. 2017). The hydrological and hydrogeological perspective of drought is very important because it affects surface and underground water resources. Recovery from hydrological and groundwater drought is usually prolonged, considering the time it takes to recharge streams and aquifers (Van Lanen et al. 2016). At a global level, more than 2.5 billion people are estimated to depend on groundwater for basic daily water needs (UN 2015). The same dependency was revealed for Eastern Romania, where more than $50 \%$ of the population lives in rural areas, where the main source of water supply comes from groundwater, exploited mainly through individual wells, with depth between 2 and $10 \mathrm{~m}$ (Minea and Croitoru 2017). The high level of dependence on groundwater resources means that communities and ecosystems are vulnerable to both natural variations of the climatic parameters as well as the impacts of anthropogenic climate change on groundwater (Minea et al. 2020a, b). Long-term manifestations, especially in the last two decades, of hydrological and hydrogeological drought in this region, require a rethinking of the water management systems, taking into account the increasing frequency and intensity of these phenomena. Moreover, the climate changes scenarios, coupled with the increasingly negative anthropic impact, in the form of significant water collection for the needs of the population, will further multiply the negative impact of drought on water resources in the region (Minea 2020).

\section{Conclusions}

Standardized evaluation indices (for precipitation-SPI, evaporation-SPEI, streamflowSDI and groundwater-SGI) have been used to analyze the drought phenomena evolution in Eastern Romania, for different time-scales (1, 3, 6 and 12 months). These were applied to seven groundwater bodies, in order to assess the link between the different types of drought. The results complement the research concerning meteorological drought (using SPI and SPEI) in the Eastern Europe region, by highlighting the drought sequences of the last two decades of the last century, as well as the meteorological drought period which started in 2007 and still continues to present times, on extensive areas. The lack of precipitation directly influences the decrease in the runoff water volume in the hydrological network and the increase in the groundwater depth. Generally speaking, natural systems exhibit a different response, both in time and space, to a context of a hydrological deficit. The evolution of meteorological, hydrological and groundwater drought in Eastern Romania, reveals a real connection between each, with sequences that exhibit a concurrent manifestation at a temporal level, especially in the last two decades. The Bravais-Pearson correlation coefficient shows a close connection between meteorological and hydrological drought $(r \sim 0.45-0.68)$ and between hydrological and groundwater drought $(r \sim 0.42-0.74)$, for wells with piezometric levels of under $5 \mathrm{~m}$, for 4 out of 7 groundwater bodies and 5 out of 7 groundwater bodies, respectively. The climate scenarios which have been developed for this region, envision, in general, an increase in the average yearly air temperature, a decrease in the hydric atmospheric input, as well as a more frequent occurrence of pluvio-thermal extreme events. Consequently, the frequency of the occurrence of drought, in all-natural components that are dependent on the hydric atmospheric input, will increase, with direct negative effects on the surface and ground water resources. This climate evolution model involves preparing well-adapted strategies, for both the geographic and 
socioeconomic conditions that are characteristic to this region, as active components of a water management plan that accounts for the long-term effects of drought phenomena.

Acknowledgements The authors thank for the hydrological and hydrogeological data provided by the Prut Barlad Basin Branch of the Romanian National Water Administration.

Funding This work was supported by a grant of the Romanian Ministry of Education and Research CNCSUEFISCDI, project number PN-III-P1-1.1-TE-2019-0286, within PNCDI III.

Open Access This article is licensed under a Creative Commons Attribution 4.0 International License, which permits use, sharing, adaptation, distribution and reproduction in any medium or format, as long as you give appropriate credit to the original author(s) and the source, provide a link to the Creative Commons licence, and indicate if changes were made. The images or other third party material in this article are included in the article's Creative Commons licence, unless indicated otherwise in a credit line to the material. If material is not included in the article's Creative Commons licence and your intended use is not permitted by statutory regulation or exceeds the permitted use, you will need to obtain permission directly from the copyright holder. To view a copy of this licence, visit http://creativecommons.org/licenses/by/4.0/.

\section{References}

Abdou A, Thierry L (2009) The sahelian standardized rainfall index revisited. Int J Climatol 29:1705-1714. https://doi.org/10.1002/joc.1832

Angearu CV, Ontel I, Boldeanu G, Mihailescu D, Nertan A, Craciunescu V, Catana S, Irimescu A (2020) Multi-temporal analysis and trends of the drought based on MODIS data in agricultural areas. Romania Remote Sens 12(23):3940. https://doi.org/10.3390/rs12233940

Bachmair S, Kohn I, Stahl K (2015) Exploring the link between drought indicators and impacts. Nat Hazard Earth Syst 15:1381-1397. https://doi.org/10.5194/nhess-15-1381-2015

Bachmair S, Svensson C, Hannaford J, Barker LJ, Stahl K (2016) A quantitative analysis to objectively appraise drought indicators and model drought impacts. Hydrol Earth Syst Sci 20:2589-2609. https:// doi.org/10.5194/hess-20-2589-2016

Bakke SJ, Ionita M, Tallaksen LM (2020) The 2018 northern European hydrological drought and its drivers in a historical perspective. Hydrol Earth Syst Sci 24:5621-5653. https://doi.org/10.5194/ hess-24-5621-2020

Barker LJ, Hannaford J, Chiverton A, Svensson C (2016) From meteorological to hydrological drought using standardised indicators. Hydrol Earth Syst Sci 20:2483-2505. https://doi.org/10.5194/ hess-20-2483-2016

Bloomfield JP, Marchant BP (2013) Analysis of groundwater drought building on the standardized precipitation index approach. Hydrol Earth Syst Sci 17:4769-4787. https://doi.org/10.5194/hess-17-4769-2013

Bloomfield JP, Marchant BP, McKenzie AA (2019) Changes in groundwater drought associated with anthropogenic warming. Hydrol Earth Syst Sci 23:1393-1408. https://doi.org/10.5194/hess-23-1393-2019

Boicu D, Minea I, Rusu C, Jora I (2020) Hydrogeological droughts evaluation in north eastern part of Romania. Aerul şi apa componente ale mediului, Edit. Presa Universitară Clujeană, Cluj-Napoca, $127-$ 134. https://doi.org/10.24193/AWC2020_12

Croitoru AE, Piticar A, Dragotă CS, Burada DC (2013) Recent changes in reference evapotranspiration in Romania. Glob Planet Chang 111:127-137

Cheval S, Busuioc A, Dumitrescu A, Birsan MV (2014) Spatio-temporal variability of meteorological drought in Romania using the standardized precipitation index (SPI). Clim Res 60:235-248. https:// doi.org/10.1007/s11069-015-2141-8

Cheval S, Dumitrescu A, Birsan MV (2017) Variability of the aridity in the South-Eastern Europe over 1961-2050. CATENA 151:74-86. https://doi.org/10.1016/j.catena.2016.11.029

Dikshit A, Pradhan B, Huete A (2021) An improved SPEI drought forecasting approach using the long short-term memory neural network. J Environ Manage 283:111979. https://doi.org/10.1016/j.jenvman. 2021.111979

Dumitrascu M, Mocanu I, Mitrica B, Dragota C, Grigorescu I, Dumitrica C (2018) The assessment of socioeconomic vulnerability to drought in Southern Romania (Oltenia Plain). Int J Disaster Risk Reduct 27:142-154. https://doi.org/10.1016/j.ijdrr.2017.09.049 
Dumitrescu A, Bojariu R, Bîrsan MV, Marin L, Manea A (2015) Recent climatic changes in Romania from observational data (1961-2013). Theor Appl Climatol 122:111-119. https://doi.org/10.1007/ s00704-014-1290-0

Dumitrescu A, Birsan MV (2015) ROCADA: a gridded daily climatic dataset over Romania (1961-2013) for nine meteorological variables. Nat Hazards 78:1045-1063. https://doi.org/10.1007/s11069-015-1757-Z

Dubrovsky M, Svoboda MD, Trnka M, Hayes MJ, Wilhite DA, Zalud Z, Hlavinka P (2008) Application of relative drought indices in assessing climate-change impacts on drought conditions in Czechia. Theor Appl Climatol 96:155-171. https://doi.org/10.1007/s00704-008-0020-X

European Drought Observatory (2021) PRODUCT FACT SHEET: Combined Drought Indicator EUROPE, http://edo.jrc.ec.europa.eu/edov2/php/index.php?id=1101, Accessed: 20 February 2021.

Field CB, Barros VR, Dokken DJ, Mach KJ, Mastrandre MD, Bilir TE, Chatterjee M, Ebi KL, Estrada YO, Genova RC, Girma B, Kissel ES, Levy AN, MacCracken S, Mastrandrea PR, White LL (eds) (2014) Climate change 2014: impacts, adaptation, and vulnerability. Part A: global and sectoral aspects. Cambridge University Press, Cambridge, p 1132

Hayes M, Svoboda M, Wiihite D, Vanyarkho O (1999) Monitoring the 1996 drought using the standardized precipitation index. Bull Am Meteor Soc 80:429-438. https://doi.org/10.1175/1520-0477(1999)080\% 3c0429:MTDUTS\%3e2.0.CO;2

Haas JC, Birk S (2019) Trends in Austrian groundwater - Climate or human impact? J Hydrol: Regional Studies 22:100597. https://doi.org/10.1016/j.ejrh.2019.100597

Hadi BM, Zhang J, Chu X (2020) Hydroclimatic aggregate drought index (HADI): a new approach for identification and categorization of drought in cold climate regions. Stoch Env Res Risk Assess 34:18471870. https://doi.org/10.1007/s00477-020-01870-5

Hanel M, Rakovec O, Markonis Y, Maca P, Samaniego L, Kysely J, Kumar R (2018) Revisiting the recent European droughts from a long-term perspective. Sci Rep 8:9499. https://doi.org/10.1038/ s41598-018-27464-4

Hao ZC, AghaKouchak A (2013) Multivariate standardized drought index: a parametric multi-index model. Adv Water Resour 57:12-18. https://doi.org/10.1016/j.advwatres.2013.03.009

Hao Z, Singh SP, Xia Y (2018) Seasonal drought prediction: advances, challenges, and future prospects. Rev Geophys. 56(1):108-141. https://doi.org/10.1002/2016RG000549

Hersbach H, Bell B, Berrisford P, Hirahara S, Horányi A, Muñoz-Sabater J et al (2020) The ERA5 global reanalysis. Q J R Meteorol Soc. 146:1999-2049. https://doi.org/10.1002/qj.3803

He B, Chang J, Wang J, Wang Y, Zhou S, Chen C (2021) Spatio-temporal evolution and non-stationary characteristics of meteorological drought in inland arid areas. Ecol Indic 126:107644. https://doi.org/ 10.1016/j.ecolind.2021.107644

Ionita M, Scholz P, Chelcea S (2015) Spatio-temporal variability of dryness/wetness in the Danube River Basin. Hydrol Process 29(20):4483-4497. https://doi.org/10.1002/hyp.10514

Ionita M, Tallaksen LM, Kingston DG, Stagge JH, Laaha G, Van Lanen HAJ, Scholz P, Chelcea SM, Haslinger K (2017) The European 2015 drought from a climatological perspective. Hydrol Earth Syst Sci 21:1397-1419. https://doi.org/10.5194/hess-21-1397-2017

Ionita M, Scholz P, Chelcea S (2016) Assessment of droughts in Romania using the Standardized Precipitation Index. Nat Hazard 81:1483-1498. https://doi.org/10.1007/s11069-015-2141-8

Kermen C, Onuşluel Gül G (2018) Comparing two streamflow-based Drought Indices. In: Gâştescu P, Bretcan $\mathrm{P}$ (eds) Water resources and wetlands, 4th International Conference Water resources and wetlands, 5-9 September 2018, Tulcea (Romania), pp 190-195

Krogulek E (2018) Evaluating the risk of groundwater drought in groundwater-dependent ecosystems in the central part of the Vistula River Valley. Pol Ecohydrol Hydrobiol 18(1):82-91. https://doi.org/10. 1016/j.ecohyd.2017.11.003

Kubicz J, Bak B (2019) The reaction of groundwater to several months' meteorological drought in Poland. Pol J Environ Stud 28(1):187-195. https://doi.org/10.15244/pjoes/81691

Kundzewicz ZW, Graczyk D, Maurer T, Pinskwar I, Radziejewski M, Svensson C, Szwed M (2005) Trend detection in river flow series: annual maximum flow. Hydrolog Sci J 50(5):810. https://doi.org/10. 1623/hysj.2005.50.5.797

Laaha G, Gauster T, Tallaksen LM, Vidal JP, Stahl K, Prudhomme C, Heudorfe B, Vlnas R, Ionita M, Van Lanen HAJ, Adler MJ, Caillouet L, Delus C, Fendekova M, Gailliez S, Hannaford J, Kingston D, Van Loon AF, Mediero L, Osuch M, Romanowicz R, Sauquet E, Stagge JH, Wong WK (2017) The European 2015 drought from a hydrological perspective. Hydrol Earth Syst Sci 21:3001-3024. https://doi. org/10.5194/hess-21-3001-2017

Leelaruban N, Padmanabhan G, Oduor P (2017) Examining the relationship between drought indices and groundwater levels. Water 9:82. https://doi.org/10.3390/w9020082 
Li Y, Gong Y, Huang C (2021) Construction of combined drought index based on bivariate joint distribution. Alex Eng J 60(3):2825-2833. https://doi.org/10.1016/j.aej.2021.01.006

Lloyd-Hughes B, Saunders MA (2002) A drought climatology for Europe. Int J Climatol 22(13):1571-1592. https://doi.org/10.1002/joc.846

Liu ZY, Tornros T, Menzel L (2016) A probabilistic prediction network for hydrological drought identification and environmental flow assessment. Water Resour Res 52(8):6243-6262. https://doi.org/10.1002/ 2016WR019106

Liu C, Yang C, Yang Q, Wang J (2021) Spatiotemporal drought analysis by the standardized precipitation index (SPI) and standardized precipitation evapotranspiration index (SPEI) in Sichuan Province. China Sci Rep 11:1280. https://doi.org/10.1038/s41598-020-80527-3

Livada I, Assimakopoulos VD (2007) Spatial and temporal analysis of drought in Greece using the standardized precipitation index (SPI). Theor Appl Climatol 89:143-153. https://doi.org/10.1007/ s00704-005-0227-z

McKee TB, Doesken NJ, Kleist J (1993) The relationship of drought frequency and duration to time scales. In: Proceedings of the 8th conference on applied climatology. Boston, pp 179-183.

Minea I, Sfîcă L (2017) Assesment of hydrological drought in the north-eastern part of Romania. Case study-Bahlui catchment area. Aerul şi apa componente ale mediului, pp 93-100. https://doi.org/ 10.24193/AWC2017_12

Minea I, Croitoru AE (2017) Groundwater response to changes in precipitation in north-eastern Romania. Environ Eng Manag J 16(3):643-651

Minea I (2020) The vulnerability of water resources from Eastern Romania to anthropic impact and climate change. In: Negm A, Romanescu G, Zeleňáková M (eds) Water resources management in Romania. Springer Water, Springer, Cham, pp 229-250. https://doi.org/10.1007/ 978-3-030-22320-5_7

Minea I, Boicu D, Iosub M, Chelariu OE, Enea A (2020a) Groundwater drought evolution in northeastern part of Romania. Int Sci Conf Geobalcanica. https://doi.org/10.18509/GBP.2020.06

Minea I, Iosub M, Boicu D (2020b) Groundwater resources from eastern Romania under human and climatic pressure. Sustainability 12(24):10341. https://doi.org/10.3390/su122410341

Mokhov II (2011) Specific features of the 2010 summer heat formation in the European territory of Russia in the context of general climate changes and climate anomalies. Izv Atmos Ocean Phys 47(6):653-660. https://doi.org/10.1134/S0001433811060119

Nalbantis I, Tsakiris G (2009) Assessment of hydrological drought revisited. Water Resour Manage 23(5):881-897. https://doi.org/10.1007/s11269-008-9305-1

Nistor MM (2019) Vulnerability of groundwater resources under climate change in the Pannonian basin. Geo-Spatial Inf Sci 22(4):345-358. https://doi.org/10.1080/10095020.2019.1613776

Ontel I, Vladut A (2015) Impact of drought on the productivity of agricultural crops within the Oltenia Plain. Romania Geogr Pannonica 19(1):9-19

Ozkaya A, Zerberg E (2019) A 40-year analysis of the hydrological drought index for the Tigris basin Turkey. Water 11(4):657. https://doi.org/10.3390/w11040657

Paltineanu C, Mihailescu IF, Prefac Z, Dragota C, Vasenciuc F, Claudia N (2008) Combining the standardized precipitation index and climatic water deficit in characterizing droughts: a case study in Romania. Theor Appl Climatol 97:219-233. https://doi.org/10.1007/s00704-008-0061-1

Prăvălie R, Piticar A, Roșca B, Sfîcă L, Bandoc G, Tiscovschi A, Patriche CV (2018) Spatio-temporal changes of the climatic water balance in Romania as a response to precipitation and reference evapotranspiration trends during 1961-2013. CATENA 172:295-312. https://doi.org/10.1016/j.catena. 2018.08.028

Peters E, Bier G, van Lanen HAJ, Torfs PJJF (2006) Propagation and spatial distribution of drought in a groundwater catchment. J Hydrol 321(1-4):257-275. https://doi.org/10.1016/j.jhydrol.2005.08.004

Rebetez M, Mayer H, Dupont O, Schindler D, Gartner K, Kropp JP, Menzel A (2006) Heat and drought 2003 in Europe: a climate synthesis. Ann Sci 63:569-577. https://doi.org/10.1051/forest:2006043

Rusu A, Ursu A, Stoleriu CC, Groza O, Niacşu L, Sfîcă L, Minea I, Stoleriu OM (2020) Structural changes in the Romanian economy reflected through Corine land cover datasets. Remote Sens 12(8):1323. https://doi.org/10.3390/rs12081323

Spinoni J, Naumann G, Vogt JV, Barbosa P (2015) The biggest drought events in Europe from 1950 to 2012. J Hydrol Region Stud 3:509-524. https://doi.org/10.1016/j.ejrh.2015.01.001

Stahl K, Kohn I, Blauhut V, Urquijo J, De Stefano L, Acácio V, Dias S, Stagge JH, Tallaksen LM, Kampragou E, Van Loon AF, Barker LJ, Melsen LA, Bifulco C, Musolino D, de Carli A, Massarutto A, Assimacopoulos D, Van Lanen HAJ (2016) Impacts of European drought events: insights from an international database of text-based reports. Nat Hazards Earth Syst Sci 16:801-819. https://doi. org/10.5194/nhess-16-801-2016 
Schwalm C, Anderegg W, Michalak A, Fisher J, Biodi F, Koch G, Livak M, Ogle K, Shaw J, Wol A, Hundzinger D, Schaefer K, Cook R, Wei Y, Fang Y, Hayes D, Huang M, Jain A, Tian H (2017) Global patterns of drought recovery. Nature 548:202-205. https://doi.org/10.1038/nature23021

Sfica L, Croitoru AE, Iordache I, Ciupertea AF (2017) Synoptic conditions generating heat waves and warm spells in Romania. Athmosfere 8(3):50. https://doi.org/10.3390/atmos8030050

Tabari H, Nikbakht J, Hosseinzadeh Talaee P (2013) Hydrological drought assessment in Northwestern Iran based on streamflow drought index (SDI). Water Resour Manage 27:137. https://doi.org/10. 1007/s11269-012-0173-3

Tallaksen LM, van Lanen HAJ (2004) Hydrological drought processes and estimation methods for streamflow and groundwater. In: Developments in water sciences 48. Elsevier, The Netherlands

Tallaksen LM, Hisdal H, van Lanen HAJ (2009) Space-time modelling of catchment scale drought characteristics. J Hydrol 375(3-4):363-372. https://doi.org/10.1016/j.jhydrol.2009.06.032

Trenberth K, Dai A, van der Schrier G, Jones P, Barichivich J, Briffa GR, Sheffiel J (2014) Global warming and changes in drought. Nature Clim Change 4:17-22. https://doi.org/10.1038/nclimate2067

Tsakiris G, Pangalou D, Vangelis H (2007) Regional drought assessment based on the Reconnaissance Drought Index (RDI). Water Resour Manage 21:821-833. https://doi.org/10.1007/s11269-006-9105-4

Tigkas D, Vangelis H, Tsakiris G (2015) DrinC: a software for drought analysis based on drought indices. Earth Sci Inform 8(3):697-709. https://doi.org/10.1007/s12145-014-0178-y

UN (2015) Water for a sustainable world. The United Nations World Water Development Report http:// unesdoc.unesco.org/images/0023/002318/231823E.pdf. Accessed: 20 March 2021

Van Lanen HAJ, Wanders N, Tallaksen LM, Van Loon AF (2013) Hydrological drought across the world: impact of climate and physical catchment structure. Hydrol Earth Syst Sci 17(5):1715-1732. https:// doi.org/10.5194/hess-17-1715-2013

Van Lanen HAJ, Laaha G, Kingston DG, Gauster T, Ionita M, Vidal JP, Vlnas R, Tallaksen LM, Stahl K, Hannaford J, Delus C, Fendekova M, Mediero L, Prudhomme C, Rets E, Romanowicz RJ, Sebastien G, Wong WK, Adler MJ, Blauhut V, Caillouet L, Chelcea S, Frolova N, Gudmundsson L, Hanel M, Haslinger K, Kireeva M, Osuch M, Sauquet E, Stagge JH, Van Loon AF (2016) Hydrology needed to manage droughts: the 2015 European case. Hydrol Process 30(17):3097-3104. https://doi.org/10.1002/ hyp. 10838

van Loon AF (2015) Hydrological drought explained. Wires Water 2:359-392

Vicente-Serrano SM, López-Moreno JI (2005) Hydrological response to different time scales of climatological drought: an evaluation of the standardized precipitation index in a mountainous Mediterranean basin. Hydrol Earth Syst Sci 9:523-533. https://doi.org/10.5194/hess-9-523-2005

Vicente-Serrano SM (2006) Differences in spatial patterns of drought on different time scales: an analysis of the Iberian Peninsula. Water Resour Manage 20:37-60. https://doi.org/10.1007/s11269-006-2974-8

Vicente-Serrano SM, Beguería S, López-Moreno JI (2010) A multiscalar drought index sensitive to global warming: the standardized precipitation evapotranspiration index. J Clim 23:1696-1718. https://doi. org/10.1175/2009JCLI2909.1

Vicente-Serrano SM, López-Moreno JI, Lorenzo-Lacruz J, El Kenawy A, Azorin-Molina C, Morán-Tejeda E, Pasho E, Zabalza J, Begueria S, Angulo-Martinez M (2011) Hydrological, socioeconomic and ecological impacts of the North Atlantic Oscillation in the Mediterranean region. In: Vicente-Serrano $\mathrm{S}$, Trigo R (eds) Advances in global change research, vol 46. Springer, Dordrecht. https://doi.org/10. 1007/978-94-007-1372-7_3

Vicente-Serrano SM, López-Moreno JI, Beguería S, Lorenzo-Lacruz J, Azorin-Molina C, Morán-Tejeda E (2012) Accurate computation of a streamflow drought index. J Hydrol Eng 17(2):318-332. https://doi. org/10.1061/(ASCE)HE.1943-5584.0000433

Vicente-Serrano SM, Quiring SM, Peña-Gallardo M, Yaun S, Dominguez-Castro F (2020) A review of environmental droughts: increased risk under global warming? Earth-Sci Rev 201:102953. https://doi. org/10.1016/j.earscirev.2019.102953

Wang W, Ertsen M, Svoboda M, Hafeez M (2016) Propagation of drought: from meteorological drought to agricultural and hydrological drought. Adv Meteorol 2016:5. https://doi.org/10.1155/2016/6547209

Waseem M, Ajmal M, Kim TW (2015) Development of a new composite drought index for multivariate drought assessment. J Hydrol 527:30-37. https://doi.org/10.1016/j.jhydrol.2015.04.044

World Meteorological Organization (WMO) (2012) Standardized precipitation index user guide. In: Svoboda M, Hayes M, Wood D (eds) WMO-No. 1090, WMO Geneva, Switzerland

World Meteorological Organization (WMO) (2016) Integrated drought management program (IDMP). Handbook of drought indicators and indices. No 1173, 45

Wu H, Svoboda MD, Hayes MJ, Wilhite DA, Wen F (2007) Appropriate application of the Standardized Precipitation Index in arid locations and dry seasons. Int J Climatol 27(1):65-79. https://doi.org/10. 1002/joc. 1371 
Yeh CF, Wang J, Yeh HF, Lee CH (2015) SDI and Markov chains for regional drought characteristics. Sustainability 7(8):10789-10808. https://doi.org/10.3390/su70810789

Zhao R, Wang H, Chen J, Fu G, Zhan C, Yang H (2021) Quantitative analysis of nonlinear climate change impact on drought based on the standardized precipitation and evapotranspiration index. Ecol Indic. https://doi.org/10.1016/j.ecolind.2020.107107

Publisher's Note Springer Nature remains neutral with regard to jurisdictional claims in published maps and institutional affiliations. 